\title{
A Corpus-Driven Analysis of Media Representations of the Chinese Dream
}

\author{
Zhide $\mathrm{Hou}^{1}$ \\ ${ }^{1}$ Shenzhen Tourism College of Jinan University, Shenzhen, China \\ Correspondence: Zhide Hou, Shenzhen Tourism College of Jinan University, Shenzhen, Guangdong 518053, \\ China. Tel: 86-189-3807-5097. E-mail: zidhou@jnu.edu.cn
}

Received: August 26, 2015

Accepted: September 14, 2015 Online Published: January 31, 2016

doi:10.5539/ijel.v6n1p142

URL: http://dx.doi.org/10.5539/ijel.v6n1p142

\begin{abstract}
The Chinese dream describing a set of ideals received numerous media reports after its proclamation by Chinese President Xi Jinping in November 2012. Making use of the rich source of media data, this article explores the ideology and ideals of the Chinese Dream represented in China's state-run English-language newspapers. Modeled on the approach of corpus-driven discourse studies and combining the theoretical framework and methodological approaches of Critical Discourse Analysis and corpus linguistics, this study attempts to yield new insights into the media representations of the Chinese Dream. A corpus of the Chinese dream is analyzed using software Concgram (Greaves, 2009) by creating information on the frequency distribution regarding the most frequently occurring two-word/three-word concgrams, and related concordance lines. Findings shown Chinese President Xi's speech on the Chinese Dream has strong control of ideological positions in media representations.
\end{abstract}

Keywords: the Chinese Dream, media discourse, corpus-driven, control, Critical Discourse Analysis

\section{Introduction}

On November 29, 2012, soon after the conclusion of the 18th National Congress of the Communist Party of China (CPC), Chinese President Xi Jinping put forward, for the first time, the idea of the Chinese Dream on a visit to "The Road towards Renewal" exhibition at the National Museum of China. In March 2013, he further elaborated on the Chinese Dream in his keynote speech at the closing ceremony of the First Session of the 12th National People's Congress. Since then, he has talked about the concept on a number of occasions. President Xi stressed that the Chinese Dream means "the great rejuvenation of the Chinese nation". It embodies achieving prosperity for the country, rejuvenation or renewal of the nation and happiness for the citizens. Only when the country is doing well, can the nation and people do well. Xi stressed that all the Chinese people have the opportunity to enjoy a successful life, to realize one's dream, and to grow and progress together with the country. $\mathrm{Xi}$ also emphasized the Chinese Dream is a dream for peace, development, cooperation and mutual benefit for all. The Chinese Dream has becoming ubiquitous in the People's Republic: it's featured in newspapers editorials, TV debates and elementary-school textbooks. It is also widely used by journalists, government officials, and activists to describe the role of the individual in the Chinese society.

Projected as hot media reports after Chinese President Xi's speech, the Chinese Dream also spurred a burst of production in China's state-run English-language newspapers. Making use of the rich source of data, this article explores the ideological representations of the Chinese Dream in media discourses after Chinese President Xi's talk. Modeled on the approach of "corpus-driven" (Tognini-Bonelli, 2001, p. 11) and Critical Discourse Analysis (van Dijk, 2008), this paper aimed at uncovering the qualities, characteristics and values attributed to the Chinese Dream, and its political and ideological representations in media discourse.

\section{Ideology in Media Discourse}

Media discourse, the primary source of understanding the world, can refer to "a totality of how reality is represented in broadcast and printed media from television to newspapers" (O'Keeffe, 2006, p. 1). It has the power of manipulating ideational and interpersonal information and thus communicates ideology (Hart, 2010). As Garrett and Bell (1998, p. 3) noted, "media use can tell us a great deal about social meanings and stereotypes projected through language and communication". Media plays an important role in providing us with rich 
resources about what is happening around the world in this information era. In line with the understanding of media discourse as a product of societal and institutional practice (Hakam, 2009), China's state-run English-language newspapers can be described as both a product of society and a shaper of its discourse. While China's state-run English-language newspapers studied in this article may politically and ideologically motivated, because news-editing rules are expected to conform to Chinese norms and values, and serve for the Chinese government under CPC. As Fairclough (2001, pp. 43-45) noted, "the mass media plays a pivotal role in the establishment and perpetuation of power relationships, as it is through the discursive practices of the media that the dominant ideology is disseminated and reinforced".

Fowler (1991, p. 10) noted that "anything that is said or written about the world is articulated from a particular ideological position". He identified "over lexicalization" in which the media apply an excess of labels to a particular kind of person. Fairclough (1992) takes the view that ideology is meaning in the service of power, that is, ideologies are propositions that generally figure as implicit assumptions in texts, which contribute to producing or reproducing unequal relations of power or dominance. van Dijk (1998) has provided a comprehensive study of the intricate relationships among discourse, ideology, and media. He observed that the media as ideological institutions have taken over the ideological work of the family, the Church, and the school in contemporary information society.

Given the increasing control of the elites of the mass media, and the increasing role of the mass media as the major means of ideological control of society, elite ideologies will generally tend to dominate (Kuo \& Nakamura, 2005). The Chinese dream, as a patriotic slogan and a dream of a powerful state under the new leadership of $\mathrm{CPC}$, is discursively represented in media discourses chiefly contributed to the legitimacy for the new standing committee of $\mathrm{CPC}$, allowing the ideological underpinnings to be unpacked through the analysis of the linguistic forms across the corpus of the Chinese Dream in this article.

\section{Critical Discourse Analysis and Corpus-based CDA}

The focuses of theoretical concepts of Critical Discourse Analysis (CDA) are power, ideology and domination (Fairclough, 1985; Fairclough \& Wodak, 1997). The term ideology can refer to different concepts, ranging from a particular political stance to a set of beliefs held by an individual or group of people (Adolphs, 2006, p. 84). CDA provides a general framework for discursive event regarding dominance and inequality. As noted by Cheng \& Lam (2013, p. 174), "the major theoretical approaches in CDA have been developed due to varying historical backgrounds, theoretical orientations and research focuses". CDA has become "one of the most influential and visible branches of discourse analysis" since its inception (Blommaert \& Bulcean, 2000, p. 447). Most CDA studies focus on the representation of political discourse (Graber, 1981; Cheng, 2006; van Leeuwen, 2008). As noted by van Dijk (2001), "political discourse is eminently ideological" and in order to construct ideology "the concept of identity" is essential.

The present study adopts van Dijk's (2008) theoretical framework that critically relates the complex relation between discourse and power. According to him, power is defined in terms of control, that is, "control of one group over other groups and their members" (van Dijk, 2008, p. 9). He observed that such "control does not only apply to discourse as social practice, but also to the minds of those who are being controlled" (ibid). The reproduction of power through discourse is summarized as context control, discourse control and mind control. As for context control, powerful elites or organizations may decide who participate in some communicative event, when, where and with what goals. Structures of discourse are being controlled in terms of topic, style, order, speech acts and communicative acts. Mind control, as van Dijk (2008, p. 11) observed, "involves much more than just understanding text or talk, but also personal and social knowledge, previous experiences, personal opinions and social attitudes, ideologies and norms or values, among other factors that play a role in changing one's mind". van Dijk noted that, "a central notion in most critical work on discourse is that of power, and more specifically the social power of groups or institutions" (van Dijk, 2001, p. 354). Those groups who control most influential discourse, like President Xi's speech on the Chinese dream through public discourse in this study, also has more chances to control the minds and actions of others (ibid).

Despite its theoretical vantage in addressing social events and promoting social change, CDA has not escaped criticism as Widdowson (2004) accuses that the methodological grounds are over-subjective in the analysis of texts because it is directed by political commitment. Other criticisms to CDA are the arbitrariness of selected texts, methodologically "unsystematic" (Rogers, 2004, p. 4) and "anecdotal" (McCabe et al., 2009). The corpus-driven approach to the study of interactions in the media offers the researcher a reasonably high degree of objectivity. The advent of computers and especially their capacity to store and process masses of data facilitates the systematic analysis of large amounts of language. As noted by O'Keeffe (2006, p. 50), the corpus-based 
approach to the analysis of language in the media allows for "the quantification of recurring linguistic features to substantiate qualitative insights as well as the qualification of quantified findings". The present study adopts the corpus-driven CDA that goes beyond small samples of texts and conveniently explore quantitative patterns of ideological meaning in a large number of texts before carrying out qualitative analysis. As O'Halloran (2010, p. $565)$ notes, "quantitative data mined from a corpus can usefully ground qualitative analysis and in so doing help to enhance methodological rigor."

Media discourse is of vast volume and heterogeneity. Corpus linguistics has been increasingly used in critical discourse studies to examine the discursive events of politics (Johnson et al., 2003; Prentice, 2010), religion (Salama, 2011), climate (Koteyko, 2010), refugees (Baker, 2008) and gender issues (Page, 2003; Jaworska \& Krishnamurthy, 2012), uncovering the existence of language patterns and messages otherwise unobserved. As Cheng \& Lam (2013, p. 177) noted that in critical analysis of media discourse, "discursive events regarding dominance and inequality", "language use for manipulative purposes", "discriminatory discursive practices" and "national conflict" are favorite sites of research.

Alongside the methodological contribution of CDA, adopted in the investigation of discursive patterns and strategies (Van Dijk, 2001; Wodak, 2001), and Corpus linguistics, a quantitative dimension to the analysis (Baker et al., 2008), it is argued that the value of corpus-driven CDA makes it possible to a quick analysis of large media text collections in a relatively short amount of time because of the use of corpus software to the frequency lists, $\mathrm{N}$-grams, concordance, collocation and etc. through the analysis of lexical and semantic patterns.

\section{Methodology}

To investigate the media representations of the Chinese Dream in China's state-run English-language newspapers, the Chinese Dream Corpus (CDC) of 30 articles with 15,871 words in total were retrieved from the major English-language newspapers (i.e., China Daily, People's Daily Online and the Xinhua News Agency and Beijing Review) in a time span of three months since Xi's talk on the Chinese Dream on 29 November 2012. One important consideration of choosing data from China's state-run English-language newspapers is that they represent Chinese government's ideologically construed social and political positions to international readers. All the articles are retrieved by the search term Chinese dream or China dream in the aforementioned websites. The criterion for selecting articles is to ensure the Chinese Dream the primary topic of the article, that is, it has to appear in the title. This is done with a view to including only articles in which Chinese Dream is discussed as the major topic and to exclude texts in which the two words are mentioned only in passing.

The corpus is analyzed using Concgram 1.0 (Greaves, 2009) by creating information on the frequency distribution regarding the most frequently occurring two-word and three-word concgrams. Concgrams include all of the configurations of the co-occurring words irrespective of any constituency (AB, ACB) and/or positional $(A B, B A)$ variation. Cheng, Greaves \& Warren's (2006) research revealed that concgrams are a useful source of raw data, and make the search a true corpus-driven analysis (Tognini-Bonelli, 2001). The function/grammatical words are excluded at the first step because the focus is on "lexical items" (Baker, 2006, p. 100). The second step is to examine the most frequently occurring three-word concgrams. But the function/grammatical words are not excluded at this step because the two-word concgrams retrieved in the first step combining with grammatical words form recurrent lexical-grammatical patterns (or chunks) that can specify or modify the meaning of the two-word concgrams (Sinclair, 1991). The third step is to examine the relevant concordance lines which can provide "a window into the underlying ideological assumptions and values of linguistic manifestation" (Cheng \& Lam, 2013, p. 180).

\section{Discussion and Findings}

\subsection{Two-word Concgrams}

As Table 1 illustrated below, the top ten most frequently occurring two-word concgrams, with the exclusion of function words, tells the dominant theme on the Chinese dream. The highly frequent occurring words Chinese/China/dream/Mr.Xi strongly indicated that the Chinese Dream is a matter featured predominantly, and facilitates the process of uncovering a certain type of ideology on the Chinese dream from that of Mr. Xi's, the Chinese President. 
Table 1. The top 10 most frequently occurring two-word concgrams in CDC

\begin{tabular}{lll}
\hline Rank & Two-word concgrams & Frequency \\
\hline 1 & Chinese/Dream & 199 \\
2 & Dream/said & 62 \\
3 & $\mathrm{Mr} / \mathrm{Xi}$ & 56 \\
4 & Chinese/said & 53 \\
5 & China/Dream & 43 \\
6 & Dream/Xi & 38 \\
7 & As/Chinese & 36 \\
8 & As/well & 36 \\
9 & Chinese/people & 36 \\
10 & As/China & 32 \\
\hline
\end{tabular}

\subsection{Three-word Concgram}

In order to capture the most frequent lexical associations of the Chinese Dream, the three-word concgrams are examined as illustrated in Table 2 below. The procedure yielded the following top 15 three-word concgrams without excluding grammatical words. Knowing the most frequently occurring three-word concgrams such as Chinese/dream/of, Chinese/dream/to, and Chinese/dream/is, the media representations of the Chinese dream can be best analyzed from their respective concordance lines.

Table 2. The top 15 most frequently occurring three-word concgrams in the Chinese Dream Corpus

\begin{tabular}{lll}
\hline Rank & Three-word concgrams & Frequency \\
\hline 1 & Chinese/Dream/the & 283 \\
2 & Chinese/Dream/of & 129 \\
3 & Chinese/said/the & 83 \\
4 & Dream/said/the & 80 \\
5 & Chinese/Dream/a & 73 \\
6 & Chinese/people/the & 73 \\
7 & Chinese/nation/the & 71 \\
8 & Chinese/Dream/to & 65 \\
9 & Dream/people/the & 57 \\
10 & Chinese/Dream/and & 50 \\
11 & Dream/world/the & 48 \\
12 & Mr./Xi/the & 48 \\
13 & As/Chinese/the & 46 \\
14 & Chinese/Dream/is & 46 \\
15 & China/Dream/the & 45 \\
\hline
\end{tabular}

In order to see what attributes are frequently associated with Chinese dream, the most frequent collocates appearing to the immediate left of the pattern of/Chinese/dream are examined.

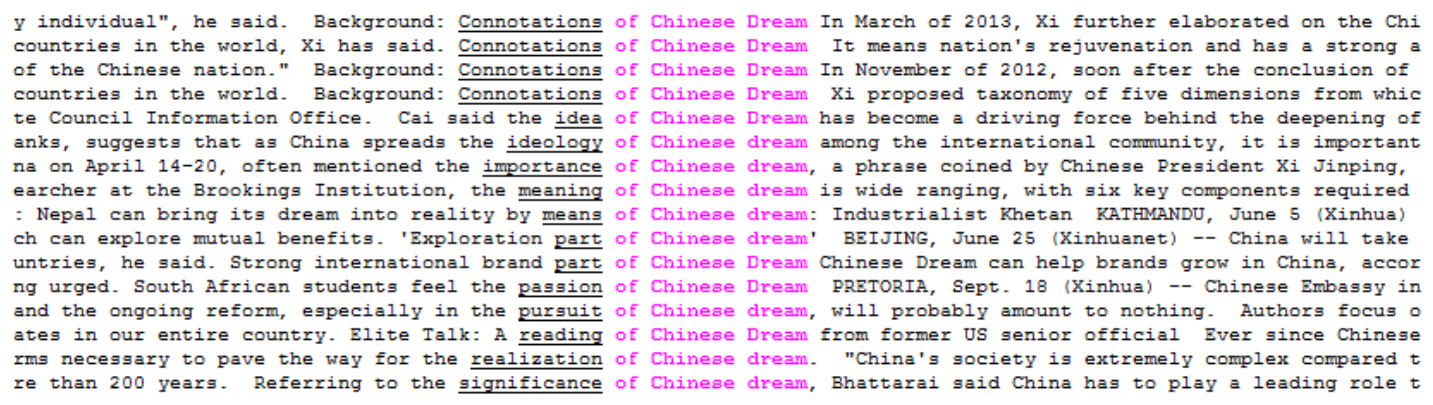

Figure 1. Sample concordances of the three-word Concgram Chinese/dream/of

Among the 129 co-occurrences of the three-word Concgram Chinese/dream/of, the two contiguous patterns of Chinese Dream and of the Chinese Dream are examined to find the paradigmatic association with nouns at N-1 
such as realization, understanding, idea, connotations, concept, interpretations, meaning, nature, potential, significance and so on, all of which contributed to heated media representations of final success and interpretations of the Chinese Dream as a new concept in the context of new leadership in China. The most frequent co-occurring word with realization (15 times) implied the agreement of ideological positions of Chinese media with what Chinese President Xi proclaimed of the Chinese Dream.

The three-word Concgram Chinese/dream/to provided further indicative results. The most frequent collocates to the right side of the pattern are followed by verbs such as pursue, have, embrace, foster, shape, establish, inspire, fulfill, and transform. These are indeed aspects of what China positively positioned in the pursuit of their Chinese dreams. To have car and house as the first concordance line reads, is the real dream of the Chinese people in this modern society. This pattern seems to suggest the Chinese Dream is design to inspire rather than inform.

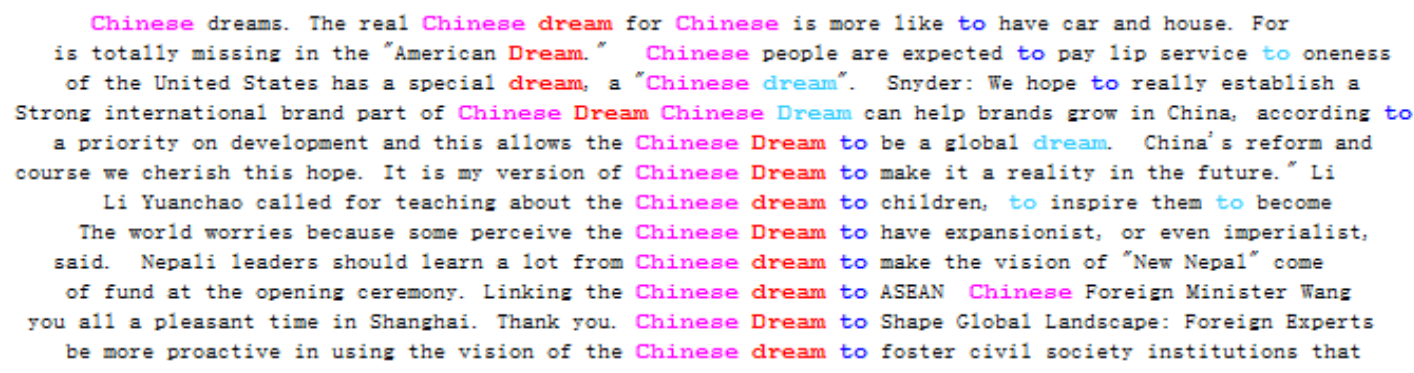

Figure 2. Sample concordances of the three-word Concgram Chinese/dream/to

The last pattern examined is the three-word Concgram Chinese/dream/is. About half of the words to the right side of the pattern are $a /$ an at $\mathrm{N}+1$, but further analysis of the concordances for this pattern strongly indicated a positive semantic preference given the words and phrases associated with are development, peace, whole humanity, cooperation, better life, social goal, civilization, vision, ideal, strong nation, and new concept. These interpretations or definitions provided the quality and value of Chinese dream concerning a promising future of human civilization for the whole world. This is also a reformulation of the Chinese dream, echoing the "understanding of the original" (Blakemore, 1993, p. 107) elaboration of the Chinese Dream by the Chinese President Xi.

for international security. It has contributed to world peace. The Chinese dream is a dream for development. Chinese people focus
with the history trend and echoes the world expectation. The Chinese dream is a dream for peace. Adhering to the peaceful
Communist party of Nepal (Maoist) Baburam Bhattarai said that Chinese dream is a dream of whole humanity as well as of
in his party, said in a recent exclusive interview with Xinhua, that Chinese dream is a dream of oppressed humanity of the world
of human being's common dream - development. The Chinese dream is a dream for cooperation. The interrelation and
and progress together with the country. Xi also emphasized that the Chinese Dream is a dream for peace, development, cooperation
long-lasting peace and common prosperity for the world. The Chinese Dream is a vision The first time President Xi Jinping said
of the Chinese nation's rejuvenation. Just as President Xi said, the Chinese dream is a dream of national strength, prosperity and
the Chinese dream and improving human rights in the country. "The Chinese dream is a social goal and vision containing the concepts
secure future. For an ordinary family, however, the key factor in the Chinese Dream is a better life. And keeping housing prices within
the nation and happiness for citizens. Xi also emphasized that the Chinese Dream is a dream for peace, development, cooperation
provoked questions and elicited wonder on the other. Certainly, the Chinese dream is a grand overarching vision that has become a
the chance to grow and progress with the country, Xi has said. The Chinese Dream is a dream for peace, development, cooperation

Figure 3. Concordances of the three-word Concgram Chinese/dream/is

\subsection{Discourse and Power}

The speech on the Chinese dream delivered by Chinese President Xi is a discourse at the micro level of social interaction in the specific situation, but at the same time enacts a constituent part of political doctrine of the new standing committee of CPC at the macro level. The discourse-circle between the Chinese dream and CPC with Chinese President Xi indicated Xi's elaboration on the Chinese Dream was the most influential discourse which has more chances to control.

Firstly, the Chinese dream, a public discourse delivered by Chinese President Xi, was an important "symbolic resource" (van Dijk, 2001) for the Chinese people, because President Xi, leader of CPC, has more or less 
exclusive access to, and control over public discourse in China. Xi's focus on the "national rejuvenation" as the goal of the Chinese Dream in his speech has been reformulated numerously by China's state-run English-language newspapers. This is a strong indication of elite ideological dominance of discourse control in China's media representations.

Secondly, according to van Dijk (2008), controlling people's minds is the other fundamental way to reproduce dominance and hegemony. The belief of the Chinese Dream by President Xi through public discourse is seen as authoritative and trustworthy. The numerous reformulations of the qualities and values of the Chinese Dream reported in China's state-run English-language newspapers are evident control of people's mind.

Thirdly, as for the context control, take the setting of time and place as an example, Chinese President Xi chose to initiate the Chinese Dream two weeks after his appointment as CPC's general secretary and military commander-in-chief at the National Museum where an exhibition named "The Road towards Renewal" took place. The theme of the exhibition runs in the same groove with what Xi proclaimed of the Chinese Dream as "national rejuvenation of the Chinese nation". Given the special time and place of the communicative event like this, President Xi, together with his standing committee of CPC, in the National Museum displayed a strong sense of resolution and responsibility through public discourse on the Chinese Dream, all of which contributed to an image of CPC firm control of context.

\section{Conclusion}

By conducting a corpus-driven CDA of the media reports on the Chinese Dream from the corpus of China's state-run English-language newspapers that integrates the theories and methods of corpus linguistics and CDA, this study has demonstrated how the two areas of linguistic enquiry can be effectively and fruitfully combined, and the great potential of using Concgram (Greaves, 2009). Chinese President Xi's public speech on the Chinese Dream has shown dominant influence and firm control on ideological positions of media representations. The numerous reformulations of the Chinese Dream from media reports characterized as success, inspiration, peace and development, and promising future are best evident of the power of the Chinese Government in media control. The findings gave insights into a new understanding of the Chinese Dream when newly elected Chinese President Xi with his new standing committee of CPC made resolutions of development and reform in building China into a moderately prosperous country.

\section{References}

Adolphs, S. (2006). Introducing electronic text analysis: a practical guide for language and literary studies. New York: Routledge. http://dx.doi.org/10.4324/9780203087701

Baker, P. (2006). Using corpora in discourse analysis. London: Continuum.

Baker, P., Gabrielatos, C., Khosravinik, M., Krzyzanowski, M., McEnery, T., \& Wodak, R. (2008). A useful methodological synergy? Combining critical discourse ana- lysis and corpus linguistics to examine discourses of refugees and asylum seekers in the UK newspapers. Discourse and Society, 19(3), 273-306. http://dx.doi.org/10.1177/0957926508088962

Blakemore, D. (1993). The relevance of reformulations. Language and Literature, 2, 101-120. http://dx.doi.org/10.1177/0963947009105341

Blommaert, J., \& Bulcean, C. (2000). Critical discourse analysis. Annual Review of Anthropology, 29, 447-466. http://dx.doi.org/10.1146/annurev.anthro.29.1.447

Cheng, M. (2006). Constructing a new political spectacle: tactics of Chen Shui-bian's 2000 and 2004 inaugural speeches. Discourse and Society, 17(5), 583-608. http://dx.doi.org/10.1177/0957926506066297

Cheng, W., \& Lam, P. W. Y. (2013). Western perceptions of Hong Kong ten years on: a corpus-driven critical discourse study. Applied Linguistics, 34(2), 173-190. http://dx.doi.org/10.1093/applin/ams038

Cheng, W., Greaves, C., \& Warren, M. (2006). From n-gram to skipgram to concgram. International Journal of Corpus Linguistics, 11(4), 411-433. http://dx.doi.org/10.1075/ijcl.11.4.04che

Fairclough, N. (1985). Critical and descriptive goals in discourse analysis. Journal of Pragmatics, 9, 739-763. http://dx.doi.org/10.1016/0378-2166(85)90002-5

Fairclough, N. (1992). Discourse and Social Change. Cambridge: Polity Newspapers. http://dx.doi.org/10.1177/0957926592003002008

Fairclough, N. (2001). Language and power. New York: Longman. http://dx.doi.org/10.1017/S0047404500009064 
Fairclough, N., \& Wodak, R. (1997). Critical discourse analysis. In T. A. van Dijk (Ed.), Discourse as Social Interaction (pp. 258-84). SAGE. http://dx.doi.org/10.4135/9780857028020.n6

Fowler, R. (1991). Language in the News: Discourse and Ideology in the Newspapers. London: Routledge. http://dx.doi.org/10.5860/CHOICE.29-1923

Garrett, P., \& Bell, A. (1998). Media and discourse: a critical overview. In A. Bell \& P. Garrett (Eds.), Approaches to media discourse. Malden: Blackwell. http://dx.doi.org/10.1177/0957926594005001003

Graber, D. (1981). Political language. In D. Nimmo \& K. Sanders (Eds.), Handbook of Political Communication (pp. 195-224). Beverly Hills: Sage Publications. http://dx.doi.org/10.1017/S0008423900036350

Greaves, C. (2009). ConcGram 1.0: A Phraseological Search Engine. John Benjamins. http://dx.doi.org/10.1075/z.159.17ind

Hakam, J. (2009). The "cartoons controversy": a critical discourse analysis of English-language Arab newspapers discourse. Discourse and Society, 20(1), 33-57. http://dx.doi.org/10.1177/0957926508097094

Hart, C. (2010). The critical discourse analysis and cognitive science: new perspectives on immigration discourse. Palgrave Macmillan. http://dx.doi.org/10.1177/0957926512450064b

Jaworska, S., \& Krishnamurthy, R. (2012). On the F word: a corpus-based analysis of the media representation of feminism in British and German newspapers discourse, 1990-2009. Discourse and Society, 23(4), 401-431. http://dx.doi.org/10.1177/0957926512441113

Johnson, S., Jonathan, C., \& Stephanie, S. (2003). From "politically correct councillors" to "Blairite nonsense": discourse of "political correctness" in three British newspaperss. Discourse and Society, 14(1), 29-47. http://dx.doi.org/10.1177/0957926503014001928

Koteyko, N. (2010). Mining the internet for lingusitc and social data: an analysis of "carbon compounds" in web feeds. Discourse and Society, 21(6), 655-674. http://dx.doi.org/10.1177/0957926510381220

Kuo, S. H., \& Nakamura, M. (2005). Translation or transformations? A case study of language and ideology in the Taiwanese newspapers. Discourse and Society, 16(3), 393-417. http://dx.doi.org/10.1177/0957926505051172

McCabe, A., O’Donnell, M., \& Whittaker, R. (2009). Continuum (Eds.), Advances in language and education. Continuum. http://dx.doi.org/10.4324/9780203856949.ch40

O'Halloran, K. (2010) How to use corpus linguistics in the study of media discourse. In A. O'Keeffe \& M. McCarthy (Eds.), The Routledge handbook of corpus linguistics (pp. 563-577). New York: Routledge. http://dx.doi.org/10.4324/9780203856949.ch40

O’Keeffe. (2006). Investigating media discourse. New York: Routledge.

Page, R. E. (2003). "Cherie: lawyer, wife, mum": contradictory patterns of representation in media reports of Cherie Booth/Blair. Discourse and Society, 14(5), 559-579. http://dx.doi.org/10.1177/09579265030145002

Prentice, S. (2010). Using automated semantic tagging in critical discourse analysis: a case study on Scottish independence from a Scottish nationalist perspective. Discourse and Society, 21(4), 405-437. http://dx.doi.org/10.1177/0957926510366198

Rogers, R. (2004). An introduction to critical discourse analysis in education. Lawrence Erlbaum Associates. http://dx.doi.org/10.1177/0957926512450048d

Salama, A. H. Y. (2011). Ideological collocation and the recontextualization of Wahhabi-Saudi Islam post-9/11: a synergy of corpus linguistics and critical discourse analysis. Discourse and Society, 22(3), 315-342. http://dx.doi.org/10.1177/0957926510395445

Sinclair, J. (1991). Corpus, concordance, collocation. Oxford: Oxford University Newspapers. http://dx.doi.org/10.2307/330144

Tognini-Bonelli, E. (2001). Corpus linguistics at work. Hohn Benjamins. http://dx.doi.org/10.1075/scl.6

van Dijk, T. A. (1998). Ideology: A Multidisciplinary Approach. Newbury Park, CA: Sage.

van Dijk, T. A. (2001) Critical discourse analysis. In D. Schiffrin, D. Tannen, \& H. E. Hamilton (Eds.), The handbook of discourse analysis (pp. 352-371). Blackwell.

van Dijk, T. A. (2008). Discourse and Context: A Sociocognitive Approach. Cambridge University Newspapers. http://dx.doi.org/10.1017/cbo9780511481499 
van Leeuwen, M. (2008). The styles of political speeches: problems in existing methods. Online Proceedings of the Annual Conference of the Poetics and Linguistics Association (PALA). Retrieved from http://www.pala.ac.uk/resources/proceedings/2008/Maarten 2008.pdf

Widdowson, H. G. (2004). Text, context, pretext: critical issues in discourse analysis. Oxford: Blackwell. http://dx.doi.org/10.1002/9780470758427

Wodak, R. (2001). The discourse historical approach. In R. Wodak \& M. Meyer (Eds.), Methods of critical discourse analysis (pp. 63-94). London: Sage. http://dx.doi.org/10.4135/9780857028020.n4

\section{Copyrights}

Copyright for this article is retained by the author(s), with first publication rights granted to the journal.

This is an open-access article distributed under the terms and conditions of the Creative Commons Attribution license (http://creativecommons.org/licenses/by/3.0/). 